\title{
NILAI WAKTU DARI UANG DALAM PERSPEKTIF EKONOMI ISLAM
}

\author{
M isbahul K hoir \\ Program Studi Ekonomi Syariah \\ Fakultas A gama Islam U niversitas Islam L amongan \\ e-mail: misbah.coy@gmail.com
}

\begin{abstract}
A bstract: The time value of money is associated with the current value and future value because the money received now is more worth than the money received in the future. However, is the concept of time value of money is appropriate and justified by the Shari'ah? The time value of money is a concept that says that the money of the one rupiah that can be received today is more worth than one rupiah which will be received in the future time. The concept of time value of money is needed by financial managers in making decision when will invest in an asset and determine the source of loan funds that will be chosen. M ethods for the time value of money pervade; a) the method of average rate of return. This method measures the level of profit gained by an investment. The disadvantage of this method is ignoring the time value of money; b) the payback period method. The method measures how fast the investment return is, the sooner the better; c) method of net present value (NPV). This method calculates quarrel between the current value of investment and the present value of net cash receipts in the future and calculates quarrel between the present value of cash outflow (investment) and cash inflow (income) per year; d) profitability index method (PI). This method calculates ratio between the present value of net cash receipts in the future and the present value of the investment; and e) the methods of internal rate of return (IRR). If IRR saving or profit required $\rightarrow$ decent. Islam views money as a flow concept. M oney must rotate in an economy and may not be idle for too long time. M oreover, it lets for years. Islam does not recognize the method of time value of money because this method adds value to money solely with increasing time and not effort. Islam actually knows the money value of time; that is the time has economic value as well as the money value of money. Imam Nawawi provides definition related to value addition for money based solely on the value of time is the category of riba.
\end{abstract}

Keywords: time value of money, Islamic economics

\section{Pendahuluan}

Konsep nilai waktu dari uang adalah konsep yang berkaitan dengan waktu dalam menghitung nilai uang. A rtinya, uang yang dimiliki seseorang pada hari ini tidak akan sama nilainya dengan satu tahun yang akan datang. U ang yang diterima sekarang nilainya lebih besar daripada uang yang diterima di masa mendatang. Nilai waktu dari uang berkaitan dengan nilai saat ini dan nilai yang akan datang. Suatu jumlah uang tertentu saat ini dinilai untuk waktu yang akan datang maka jumlah uang tersebut harus diakumulasikan dengan tingkat bunga tertentu (compound factor). Perbandingan jumlah uang dari periode periode 
waktu yang berbeda akan berarti. Namun, apakah konsep nilai waktu dari uang (time value of money) sesuai dan dibenarkan oleh syariah Islam?

Para pelaku ekonomi (pembuat keputusan), entah itu olahragawan, petani, peternak, artis, eksekutif bisnis, pegawai negeri atau swasta, bahkan orang tua yang menabung untuk pendidikan anak-anak mereka, harus menyesuaikan diri terhadap dampak bunga dan perubahan harga-harga ekonomi serta pajak dan zakat yang wajib dikeluarkan. Setiap bulan jutaan atau milyaran individu melakukan pembayaran hipotek atas rumah mereka belum lagi yang ikut asuransi, investasi, baik jangka panjang maupun menengah.

Dari situasi-situasi semacam ini, ada keputusan yang harus dibuat sehubungan dengan aliran kas masuk dan keluar selama satu periode waktu yang panjang. Pengambilan keputusan keuangan yang tepat mengharuskan kita mempertimbangkan nilai waktu dari uang dan apakah itu dibolehkan dalam syariat Islam? Untuk itulah pentingnya kita untuk lebih mengenal tentang apa yang dimaksud dengan nilai waktu dari uang dan bagaimana pandangan syariat Islam tentang hal itu, terutama kalau hal itu dikaitkan dengan niat, motif dan proses serta tujuan dari adanya time value of money itu sendiri. Semisal, ada yang menginvestasikan uangnya atau sekedar menabung dengan akad wadiah yad dhamanah dan ada pula yang ikut produk deposito mudharabah dengan tujuan bukan bunga atau motif lainnya melainkan supaya uangnya aman dan nilainya tetap terjaga di masa yang akan datang (tidak semakin menyusut karena adanya inflasi atau perubahan lainnya) dan bagaimana dengan mereka yang menerapkannya di bank konvensional meskipun dengan niat yang sama?

Untuk mempercepat penerapan ekonomi syariah, diperlukan upaya-upaya sistemik dan mendasar yang diharapkan dapat membentuk pola pikir dan perilaku syariah sebelum memasuki dunia kerja, bahkan semenjak memasuki pendidikan dasar. Karena tanpa sadar, mungkin saja kita melegitimasi sesuatu itu benar karena sudah terbiasa (menjadi kebiasaan) dan bukan sebaliknya, membiasakan sesuatu itu karena benar.

\section{Pengertian dan Konsep Nilai Waktu dari Uang}

Time value of money atau nilai waktu uang adalah sebuah konsep yang menyebutkan bahwa uang sebesar satu rupiah yang dapat diterima saat ini adalah lebih bernilai dibanding satu rupiah yang baru akan diterima pada waktu yang akan datang. Karena uang tersebut akan memperoleh hasil yang lebih besar bila diinvestasikan, dibanding uang yang baru dapat diterima pada masa yang akan datang.

Sedang Imam Nawawi memberikan definisi terkait penambahan nilai uang yang hanya didasarkan pada nilai waktu adalah kategori riba sebagaimana pernyataan beliau berikut:

$$
\text { طلب الزبادة في المال بزيادة الأجل }
$$

"Penambahan atas harta pokok karena unsur waktu"

Dari pengertian sementara di atas, riba dalam hutang didefinisikan sebagai penambahan atas harta pokok atau prosentase dari modal pokok karena unsur waktu tanpa adanya transaksi bisnis riil. Lalu, apakah time value of money juga identik atau serupa 
dengan riba dalam hutang? Kita akan mengetahui jawabannya dari konsep nilai waktu dari uang itu sendiri.

Konsep nilai waktu uang diperlukan oleh manajer keuangan dalam mengambil keputusan ketika akan melakukan investasi pada suatu aktiva dan pengambilan keputusan ketika akan menentukan sumber dana pinjaman yang akan di pilih. Suatu jumlah uang tertentu yang diterima waktu yang akan datang jika dinilai sekarang maka jumlah uang tersebut harus didiskon dengan tingkat bunga tertentu (discount factor).

Istilah yang digunakan :

$\mathrm{PV}=$ Present $\mathrm{V}$ alue (Nilai Sekarang)

$\mathrm{SI}=$ Simple interest dalam rupiah

$\mathrm{Fv}=$ Future $\mathrm{V}$ alue (Nilai yang akan datang)

$\mathrm{A} n=\mathrm{A} n n u i t y$ (serangkaian pembayaran yang sama selama periode waktu tertentu yang sama pula)

$\mathrm{I}=$ interest $(\mathrm{i}=$ interest $/$ suku bunga)

$\mathrm{n}=$ tahun $\mathrm{ke}$-(jumlah periode)

$\mathrm{PO}=(\mathrm{J}$ umlah pokok yang akan diakumulasikan)

Formulasi : $F V=P V(1+i)^{n}$ $P V=F V /(1+i)^{n}$

Konsep nilai waktu uang (time value of money concept) merupakan konsep yang dipahami sebagian besar orang di dunia. Teorinya: uang yang ada sekarang lebih tinggi nilainya dibandingkan jumlah yang sama di masa depan. Sebagai contoh: uang sejumlah Rp. 6.000 sekarang dapat membeli satu liter beras kualitas sedang. Namun, uang sejumlah tersebut di atas tidak dapat membeli satu liter beras pada tahun depan, mungkin 0,9 liter. Di sini terlihat bahwa secara kualitas, nilai uang tergerus seiring dengan jalannya waktu. Tergerusnya nilai uang tersebut disebut sebagai inflasi.

Inflasi muncul melalui banyak sebab. Dari sudut makro ekonomi, inflasi bisa berarti kabar yang baik (pada batasan tertentu). Jika pengangguran menurun, artinya banyak orang menerima penghasilan, artinya pula ada banyak uang yang beredar di pasar. Selaras dengan hukum penawaran dan permintaan, maka saat daya beli meningkat, karena orang-orang menerima penghasilan, maka harga-harga biasanya ikut naik. Kenaikan harga tersebut sudah kita pahami sebelumnya sebagai inflasi. M aka jelas inflasi (sekali lagi pada batas tertentu) merupakan salah satu indikator menurunnya pengangguran.

Tujuan dari rencana keuangan adalah untuk mencapai keadaan perekonomian seseorang seperti yang ditargetkan sebelumnya. Misalnya dalam keputusan memilih investasi. Jangan sampai pengorbanan sekarang yang kita lakukan, alih-alih mendapat nilai tambah, akhirnya justru menurun.

\section{Cara M engatasi Penurunan Nilai Uang}

Mengatasi penurunan nilai uang karena pengaruh inflasi dan dimakan waktu adalah dengan membuat uang tersebut produktif dan atau memberi imbal hasil melebihi laju inflasi. Cara paling efektif adalah menginvestasikan dana tersebut agar menghasilkan imbal hasil di atas laju inflasi sehingga nilai uang Anda relatif tetap atau bahkan bisa bertambah. Kalau 
semua dana dimasukkan dalam investasi yang memberi imbal hasil lebih besar dari laju inflasi, bagaimana dengan dana kebutuhan sehari-hari?

Tentu saja, kebutuhan dana sehari-hari bisa ditempatkan di bank yang besarnya sekadar untuk berjaga-jaga, sementara untuk belanja bulanan bisa menggunakan kartu kredit yang ketika tagihannya jatuh tempo A nda bayar penuh sehingga tidak dibebani bunga kredit. Dengan pola semacam ini, dana Anda bisa ditempatkan pada deposito berjangka 1 bulan yang bunganya lebih tinggi dari bunga tabungan. Dana Anda akan mendapat imbal hasil cukup tinggi dan bisa di atas laju inflasi. Di sisi lain, pengaturan uang tunai A nda juga akan bagus sebab belanja rumah tangga bisa dilakukan sekali sebulan, pakai kartu kredit, dan dibayar lunas pada awal bulan berikutnya. I tu baru dalam konteks nilai waktu uang dikaitkan dengan belanja sehari-hari yang notabene bersifat jangka pendek.

Katakanlah uang Rp. 100 juta itu ditempatkan dalam bentuk deposito berjangka dan mendapat bunga $10 \%$ per tahun. Maka, pada tahun kedua, total dana menjadi Rp. 110 juta dan tahun berikutnya menjadi Rp. 121 juta. Sementara itu, teman A nda dengan dana awal Rp. 101 juta, pada tahun kedua dananya menjadi Rp. 121 juta dan tahun berikutnya menjadi Rp. 133 juta. Bayangkan jika pokok yang ditambah bunga tersebut kemudian diinvestasikan terus-menerus dalam waktu 10 tahun. A walnya, perbedaan dana A nda dengan teman hanya Rp. 1.000.000, tetapi dalam 10 tahun kemudian perbedaannya sudah sangat besar. Ringkasnya, nilai waktu akan uang menjadi berarti jika A nda menginvestasikan dana A nda lebih besar dalam dalam kurun waktu panjang. ${ }^{1}$

Selain inflasi, kita harus memperhatikan biaya-biaya yang mungkin muncul dalam investasi kita. Seperti yang kita ketahui, sering instrumen yang kita gunakan dalam berinvestasi memerlukan biaya-biaya dalam pengelolaan atau penguasaannya. A da beberapa biaya yang muncul selama kita menguasai investasi tersebut. Contohnya adalah Pajak Bumi Bangunan (untuk investasi berupa properti), zakat (bagi seorang muslim wajib berzakat bila memiliki emas), dan lain-lain.

\section{K onsep A nuitas, Konsep N ilai W aktu dari U ang dan M etode-M etodenya}

A nuitas adalah suatu rangkaian penerimaan atau pembayaran tetap yang dilakukan secara berkala pada jangka waktu tertentu. Selain itu, anuitas juga diartikan sebagai kontrak di mana perusahaan asuransi memberikan pembayaran secara berkala sebagai imbalan premi yang telah Anda bayar. Contohnya adalah bunga yang diterima dari obligasi atau dividen tunai dari suatu saham preferen. A da dua jenis anuitas, yaitu:

a. A nuitas biasa (ordinary) adalah anuitas yang pembayaran atau penerimaannya terjadi pada akhir periode. Berdasarkan tanggal pembayarannya, anuitas biasa dapat dibagi 3 bagian:
1) Ordinary annuity
2) A nnuity due
3) Deferred annuity.

\footnotetext{
${ }^{1}$ William R. Lasher, Financial M anagement: K elayakan Bisnis (USA : Thomson South-W estren, 2008), 67
} 
a) Rumus dasar future value anuitas biasa adalah sebagai berikut: $F V n=P M T(1+i)^{n}-$ $1 / \mathrm{i}$

Keterangan :

FV $n=$ Future value (nilai masa depan dari anuitas pada akhir tahun ke-n)

PMT = Payment (pembayaran anuitas yang disimpan atau diterimapada setiap

periode)

$\mathrm{i}=$ Interest rate (tingkat bunga atau diskonto tahunan)

$\mathrm{n}=\mathrm{J}$ umlah tahun akan berlangsungnya anuitas

Contoh Estelle Company mendepositokan uang sebesar 200.000 pada setiap akhir enam bulan selama lima tahun untuk membangun pabrik produksi, agar produksinya lebih banyak, jika suku bunga 4\%, berapakah jumlah deposito tersebut pada akhir lima tahun

$=200.000(1+0,04)^{10}-1 / 0.04$

$=200.000(12,00610712)$

$=2.401 .221,425$

b) Rumus dasar present value anuitas biasa adalah sebagai berikut:PV $n=F V n 1-1$ ( 1 $+\mathrm{i}) \mathrm{ni}$

Keterangan:

PV $n=$ Present value (nilai sekarang dari anuitas pada akhir tahun ke-n)

Contoh: Perusahaan memiliki penerimaan sebesar 100.000 yang akan diterima setiap akhir tahun selama tiga tahun, perusahaan ingin mengetahui nilai sekarang dari tiga penerimaan tersebut yang didiskontokan pada $11 \%$.

$P V n=100.000(1-1 /(1+0,11) 3 / 0,11)$

$=100.000(2,443714715)$

$=244.371,4715$

b. Anuitas terhitung adalah anuitas yang pembayarannya dilakukan pada setiap awal interval. A wal interval pertama merupakan perhitungan bunga yang pertama dan awal interval kedua merupakan perhitungan bunga kedua dan seterusnya.

Rumus dasar future value anuitas terhutang:

FVn $=$ PMT ( FVIFAi,n $)(1+i)$

Contoh: A ris merencanakan untuk menikah pada umur 25 tahun, namun saat ini umur A ris baru 20 tahun, untuk mewujudkan rencananya Aris akan mendepositikan uang 500.000 tiap tanggal lahirnya, jadi mulai hari ini A ris akan mendepositokan sejumlah uang tersebut, kemudian A ris saat ini ingin mengetahui berapa uang yang akan terkumpul sampai anda umur 25 tahun, 10\% dimajemukkan secara tahunan.

$\mathrm{FV} n=(1+0,1) 5-1 / 0,1$

$=6,1051$

$=6,1051 \times 1,1$

$=6,71561 \times 500.000$

$=3.357 .805$

Keterangan : 1,1 berasal dari $1+10 \%$ 
Rumus dasar present value anuitas terhutang:

PV $n=P M T(P V I F A i, n)(1+i)$

Contoh : Estelle Company menyewa mesin pabrik dengan biaya 1.000 .000 setiap tahun yang akan dibayarkan pada awal tahun selama lima tahun, diketahui bahwa suku bunga $12 \%$.berapa nilai uang dari Estelle Company sekarang

$P V n=1.000 .000(1-1 /(1+0,12)(5-1)+1 / 0,12)$

$=1.000 .000(4,037349342)$

$=4.037 .349,342$

c. Nilai sekarang anuitas

Nilai Sekarang A nuitas adalah nilai hari ini dari pembayaran sejumlah dana tertentu yang dilakukan secara teratur selama waktu yang telah ditentukan.

d. A nuitas A badi

A nuitas abadi adalah serangkaian pembayaran yang sama jumlahnya dan diharapkan akan berlangsung terus menerus.

PV (A nuitas $A$ badi $)=$ Pembayaran $=$ PM T

e. $\quad$ ilai sekarang dan seri pembayaran yang tidak rata

Dalam pengertian anuitas tercakup kata jumlah yang tetap, dengan kata lain anuitas adalah arus kas yang sama di setiap periode. Persamaan umum berikut ini bisa digunakan untuk mencari nilai sekarang dari seri pembayaran yang tak rata:

Nilai sekarang anuitas abadi $=$ pembayaran/tingkat diskonto $=\mathrm{PMT} / \mathrm{r}$

A dapun konsep nilai waktu dari uang antara lain sebagai berikut:

a. Nilai yang akan datang (Future value)

Future value yaitu nilai uang yang akan diterima dimasa yang akan datang dari sejumlah modal yang ditanamkan sekarang dengan tingkat discount rate (bunga) tertentu.

Nilai waktu yang akan datang dapat dirumuskan sebagai berikut :

$\mathrm{FV}=\mathrm{Mo}(1+\mathrm{i}) \mathrm{n}$

K eterangan :

$\mathrm{FV}=$ Future $\mathrm{V}$ alue

Mo = Modal awal

$\mathrm{i} \quad=$ Bunga per tahun

$\mathrm{n}=$ Jangka waktu dana dibungakan

Contoh:

Tuan Juna pada 1 Januari 2010 menanamkan modalnya sebesar Rp. 100.000.000,00 dalam bentuk deposito di bank selama 1 tahun, dan bank bersedia memberi bunga $10 \%$ per tahun, maka pada 31 Desember 2010. Tuan J una akan menerima uang miliknya yang terdiri dari modal pokok ditambah bunganya.

Diketahui : $\mathrm{M} 0=100.000 .000$

$$
\begin{aligned}
\mathrm{i} & =10 \%=10 / 100=0,1 \\
\mathrm{n} & =1
\end{aligned}
$$

Jawab : 


$$
\begin{aligned}
& F V=M o(1+i) n \\
& F V=100.000 .000(1+0,10) 1 \\
& F V=100.000 .000(1+0,1) \\
& F V=100.000 .000(1,1) \\
& F V=110.000 .000
\end{aligned}
$$

Jadi, nilai yang akan datang uang milik Tuan J una adalah Rp. 110.000.000,00.

b. Nilai sekarang (Present value)

Nilai sejumlah uang yang saat ini dapat dibungakan untuk memperoleh jumlah yang lebih besar di masa mendatang. Nilai saat ini dari jumlah uang di masa datang dinilai pada tingkat bunga yang ditentukan:

$\mathrm{PV}=\mathrm{FV} /(1+\mathrm{i}) \mathrm{n}$

K eterangan:

$\mathrm{PV}=$ Present $\mathrm{V}$ alue (Nilai Sekarang)

Fv =Future $V$ alue (Nilai yang akan datang)

i $\quad=$ Interest/suku bunga

n = Jangka waktu dana dibungakan

Contoh :

Dua tahun lagi Tami akan menerima uang sebanyak R p. 50.000,00. Berapakah nilai uang tersebut sekarang jika tingkat bunga adalah $12 \%$ setahun?

Diketahui : $F v=50.000,00$

$$
\begin{aligned}
& \mathrm{i}=0,12 \\
& \mathrm{n}=2
\end{aligned}
$$

Jawab:

$$
\begin{aligned}
& \mathrm{PV}=\mathrm{Fv} /(1+\mathrm{i}) \mathrm{n} \\
& \mathrm{PV}=50.000 /(1+0,12)(2) \\
& \mathrm{PV}=50.000 / 2,24 \\
& \mathrm{PV}=22.321,43
\end{aligned}
$$

Jadi, nilai sekarang uang milik Tami adalah R p. 22.321,43,00

c. Nilai masa datang dan masa sekarang

Faktor bunga nilai sekarang PVIF $(r, n)$, yaitu persamaan untuk diskonto dalam mencari nilai sekarang merupakan kebalikan dari faktor bunga nilai masa depan FVIF $(r, n)$ untuk kombinasi $r$ dan $n$ yang sama.

$\mathrm{FV}=\mathrm{Ko}(1+\mathrm{r}) \hat{\mathrm{n}}$

Keterangan :

$\mathrm{FV}=\mathrm{Future}$ value ( Nilai mendatang)

$\mathrm{Ko}=$ arus kas awal

$\mathrm{R}=$ rate / tingkat bunga

$\mathrm{n}=$ tahun ke- $\mathrm{n}$ (pangkat $\mathrm{n}$ )

Contoh : Jika Jily menabung Rp. 5.000.000,00 dengan bunga 15\% maka setelah 1 tahun Jily akan mendapat?

Diketahui : $\mathrm{Ko}=5.000 .000$

$$
r=15 \%=15 / 100=0,15
$$




$$
\begin{aligned}
& \quad n=1 \\
& \text { Jawab: } \\
& F V=K o(1+r) \hat{n} \\
& F V=5.000 .000(1+0.15) \uparrow \\
& F V=5.000 .000(1,15) \\
& F V=5.750 .000
\end{aligned}
$$

Jadi di masa mendatang uang Jily adalah Rp. 5.750.000,-

Ketika membahas nilai waktu dari uang, maka dalam praktik ekonomi yang ada saat ini belum bisa lepas dari yang namanya bunga, sehingga secara ekonomi syariah kita harus dapat memahami dan membedakan mana bunga yang diperbolehkan dalam Islam dan mana bunga yang terlarang baik dalam transaksi pinjaman (utang-piutang), jual beli (perdagangan), baik secara tunai maupun tangguh/kredit juga transaksi di bidang jasa maupun kegiatan ekonomi lainnya.

Bunga adalah imbal jasa atas pinjaman uang. Imbal jasa ini merupakan suatu kompensasi kepada pemberi pinjaman atas manfaat kedepan dari uang pinjaman tersebut apabila diinvestasikan atau sejumlah uang yang dibayarkan atau dihasilkan sebagai kompensasi terhadap apa yang dapat diperoleh dari penggunaan uang. A da dua jenis bunga yang umum dan juga digunakan dalam perhitungan present ataupun future value yakni Bunga tunggal, Bunga majemuk.

B unga sederhana (simple interest) adalah bunga yang dibayarkan/dihasilkan hanya dari jumlah uang mula-mula atau pokok pinjaman yang dipinjamkan atau dipinjam atau bunga yang dibayar satu kali dalam setahun.

$$
\begin{aligned}
\text { Rumus : } i & =p \times r \times t \\
\text { Dengan : } i=\text { jumlah bunga sederhana } & \\
p & =\text { jumlah uang pokok } \\
r & =\text { tingkat suku bunga per periode } \\
t & =\text { waktu (jumlah periode) }
\end{aligned}
$$

Bunga majemuk atau (compound interest) adalah bunga yang dibayarkan/dihasilkan dari bunga yang dihasilkan sebelumnya, sama seperti pokok yang dipinjam/dipinjamkan atau bunga dibayar lebih dari 1 kali.

Untuk mengilustrasikan perhitungan bunga sederhana dan bunga majemuk diasumsikan bahwa uang Rp. 100.000 .000 didepositokan kesebuah bank dan dibiarkan selama 4 tahun dengan tingkat bunga $8 \%$ per tahun, pada akhir tahun pertama bunga dari uang tesebut senilai $(100.000 .000 \times 0.08 \times 1)=R p .8 .000 .000$.sehingga total uang tersebut menjadi Rp. 108.000.000 untuk tahun kedua menjadi Rp. 116.000.000 sedangkan perhitungan bunga majemuk untuk tahun pertama sama dengan bunga sederhana yatu $\mathrm{R} p$. 8.000 .000 dan total nya juga sama yaitu R p. 108.000.000, sedangkan pada tahun kedua bunga yang diterima yaiu( $8 \%$ dari total uang tahun pertama yaitu 108.000.000) sehingga bunganya menjadi $\mathrm{Rp}$. 8.640.000 sehingga total uang yang diterima yaitu Rp. 116.640 .000 tabel dibawah ini akan menggambarkan tingkat bunga sederhana dan bunga majemuk selama empat tahun dalam satuan. 


\begin{tabular}{|l|l|l|l|l|l|l|}
\hline \multirow{2}{*}{ Tahun } & \multicolumn{3}{|l|}{ B unga Sederhana } & \multicolumn{3}{l|}{ B unga M ajemuk } \\
\cline { 2 - 8 } & Perhitungan & B unga & Total & Peritungan & B unga & Total \\
\hline 1 & $(100 \times 0.08)$ & 8 & 108 & $(100,00 \times 0,08)$ & 8,00 & 108,00 \\
\hline 2 & $(100 \times 0.08)$ & 8 & 116 & $(108,00 \times 0,08)$ & 8,64 & 116,64 \\
\hline 3 & $(100 \times 0.08)$ & 8 & 124 & $(116,64 \times 0,08)$ & 9,33 & 125,97 \\
\hline 4 & $(100 \times 0.08)$ & 8 & 132 & $(125,97 \times 0,08)$ & 10,08 & 136.05 \\
\hline
\end{tabular}

a) Future Value

Future value digunakan untuk menghitung nilai investasi yang akan datang apabila uang tersebut diberikan sekarang berdasarkan tingkat suku bunga dan angsuran yang tetap selama periode tertentu kemudian definisi lain dari future value adalah nilai uang yang akan datang dari satu jumlah uang atau suatu seri pembayaran pada waktu sekarang, yang dievaluasi dengan suatu tingkat bunga tertentu.

1) Perhitungan future value dengan bunga tunggal

Untuk menghitung nilai yang akan datang kita dapat menggunakan rumus di bawah ini :

$$
\begin{aligned}
\mathrm{FV} & =\mathrm{PV}(1+\mathrm{i})^{\mathrm{n}} \\
\text { keterangan : } \mathrm{FV} & =(\text { F uture } \mathrm{V} \text { alue) nilai yang akan datang } \\
\mathrm{PV} & =(\text { Present } \mathrm{V} \text { alue) nilai saat ini } \\
\mathrm{i} & =\text { Interest (bunga) } \\
\mathrm{n} & =\text { jangka waktu }
\end{aligned}
$$

Contoh Tn. A hmad akan menginvestasikan uangnya sebesar Rp. 10.000.000 berapa jumlah uang Tn A hmad selama 2 tahun dengan bunga 10\% per tahun.

$$
\begin{aligned}
\mathrm{FV} & =10.000 .000(1+0,1)^{2} \\
& =10.000 .000 \times 1,21 \\
& =12.100 .000
\end{aligned}
$$

Jadi uang Tn. A hmad setelah 2 tahun menjadi Rp. 12.100.000,-

2) Perhitungan future value dengan bunga majemuk

Untuk menghitung nilai Uang yang akan datang datang dengan bunga majemuk Kita dapat menggunakan rumus di bawah ini :

$$
F V=P V(1+i / m)^{m} \times n
$$

Keterangan $\mathrm{FV}=$ (Future $\mathrm{V}$ alue) nilai yang akan datang

$\mathrm{PV}=($ Present $\mathrm{V}$ alue) nilai saat ini

$\mathrm{i}=$ Interest(bunga)

$\mathrm{n}=$ jangka waktu

$\mathrm{m}=$ periode yang dimajemukkan

Contoh: Tn. A hmad M enginvestasikan uangnya Rp. 50.000 .000 dengan bunga $12 \%$ per tahun berapa uang $\mathrm{T} n$. A hmad setelah 36 bulan.

$$
\begin{aligned}
& i=12 \%=0,12 \\
& n=36 / 12=3 \\
& m=12 / 3=4 \\
& F V=50.000 .000(1+0,12 / 4)^{4} \times 3
\end{aligned}
$$




$$
\begin{aligned}
& =50.000 .000(3,38) \text { dibulatkan } \\
& =169.000 .000
\end{aligned}
$$

J adi, uang Tn. A hmad setelah 36 bulan menjadi Rp. 169.000.000,-

b) Present Value

Digunakan untuk mengetahui nilai investasi sekarang dari suatu nilai di masa datang ataupun lebih sederhananya lagi menghitung nilai tunai sekarang dari sejumlah uang yang akan diterima dalam suatu periode di masa yang akan datang.

1) Perhitungan present value dengan bunga tunggal

Kita dapat menggunakan rumus di bawah ini :

$$
\begin{aligned}
\mathrm{PV}=\mathrm{FV} /(1+\mathrm{i})^{\mathrm{n}} & \\
\mathrm{K} \text { eterangan : } \mathrm{PV} & =(\text { Present } \mathrm{V} \text { alue) nilai saat ini } \\
\mathrm{FV} & =(\text { Future } \mathrm{V} \text { alue) nilai yang akan datang } \\
\mathrm{i} & =(\text { Interest) bunga } \\
\mathrm{n} & =\text { jangka waktu }
\end{aligned}
$$

Contoh: uang Tn. A mir 2 tahun yang akan datang adalah Rp. 100.000 berapa nilai uang Tn. A mir sekarang jika bunga per tahunnya $5 \%$

$$
\begin{aligned}
\mathrm{PV} & =100.000 /(1+0.05)^{2} \\
& =90702,9478 \\
& =9100 \text { dibulatkan }
\end{aligned}
$$

Jadi nilai uang Tn. A mir saat ini yaitu Rp. 9100,-

2) Perhitungan present value dengan bunga majemuk

$$
\mathrm{PV}=\mathrm{FV} /(1+\mathrm{i} / \mathrm{m})^{\mathrm{m}} \mathrm{xn}
$$

K eterangan : $F V=$ (Future $V$ alue) nilai yang akan datang

$$
\begin{aligned}
P V & =(\text { Present } V \text { alue }) \text { nilai saat ini } \\
\mathrm{i} & =(\text { Interest) bunga } \\
\mathrm{n} & =\text { jangka waktu } \\
\mathrm{m} & =\text { periode yang dimajemukkan }
\end{aligned}
$$

Contoh: uang Tn. Andi 4 tahun kedepan Rp. 500.000,- berapa uang Tn. Andi sekarang dengan bunga $6 \%$ per tahun.

$$
\begin{aligned}
\mathrm{i}= & =0,06 \\
\mathrm{n} & =4 \\
\mathrm{~m} & =12 / 4=3 \\
\mathrm{PV} & =500.000 /(1+0.06 / 3)^{3} \times 4 \\
& =117.813 .384 \\
& =118.000 \text { dibulatkan }
\end{aligned}
$$

Jadi nilai uang Tn. A ndi saat ini adalah Rp. 118.000,-

Adapun komponen-komponen yang menentukan suku bunga kredit antara lain adalah sebagai berikut:

1) Total Biaya Dana (Cost of F und)

Merupakan total bunga yang dikeluarkan oleh bank untuk memperoleh dana simpanan baik dalam bentuk simpanan giro, tabungan maupun deposito.T otal biaya dana tergantung dari seberapa besar bunga yang ditetapkan untuk 
memperoleh dana yang diinginkan. Total biaya dana ini harus dikurangi dengan cadangan wajib atau Reserve Requrement ( $R$ ) yang telah ditetapkan oleh pemerintah.

2) Biaya Operasi

Dalam melakukan kegiatan setiap bank membutuhkan berbagai sarana dan prasarana baik berupa manusia maupun alat. Penggunaan sarana dan prasarana ini memerlukan sejumlah biaya yang harus ditanggung bank sebagai biaya operasi.

3) Cadangan Risiko K redit

M erupakan cadangan terhadap macetnya kredit yang akan diberikan, hal ini disebabkan setiap kredit yang diberikan pasti mengandung suatu risiko tidak terbayar.

4) Laba yang diinginkan

Setiap kali melakukan transaksi bank selalu ingin memperoleh laba yang maksimal. Penentuan ini ditentukan oleh beberapa pertimbangan penting, mengingat penentuan besarnya laba sangat memengaruhi besarnya bunga kredit.

5) Pajak merupakan kewajiban yang dibebankan pemerintah kepada bank yang memberikaan fasilitas kredit kepada nasabahnya.

Selain bunga, kita sering mendengar mengenai suku bunga. Suku bunga adalah persentase pokok utang (besar uang yang dipinjam) yang dibayarkan sebagai balas jasa. B eberapa faktor yang mempengaruhi besar kecilnya suku bunga tersebut antara lain: kebutuhan dana, persaingan, kebijakan pemerintah, target laba yang diharapkan, jangka waktu (peminjaman atau penanaman), kualitas jaminan yang diberikan, jaminan pihak ketiga, reputasi perusahaan, jenis produk, dan hubungan baik antara bank dan nasabah. Istilah bunga yang digunakan dalam jasa keuangan ada banyak, di antaranya yaitu:

1) Bunga flat, bunga jenis ini sistem pembayaran utang pokok dan bunga kredit besarnya akan sama setiap bulannya. Nilai bunga akan tetap sama setiap bulannya karena sistem ini menghitung dari awal. Maksudnya, bunga dihitung dari persentasi bunga yang dikalikan pokok pinjaman awal. Bunga jenis ini biasanya digunakan pada peminjaman jangka pendek ataupun kendaraan.

2) Bunga efektif, di mana besar bunga dihitung berdasarkan nilai pokok yang belum dibayar dan dilakukan di setiap akhir periode angsuran. Nilai bunga yang dibayar akan semakin mengecil sehingga angsuran perbulan juga akan semakin menurun dari waktu ke waktu. Perhitungan demikian tidak berarti bahwa bunga efektif akan lebih rendah dibandingkan bunga flat.

3) Bunga anuitas, pada bunga ini porsi atau komposisi bunga dan pokok akan berubah setiap periodenya, akan tetapi besar angsuran tetap sama setiap periodenya. Di mana, untuk perhitungannya porsi bunga pada awal akan sangat besar sedangkan pokoknya kecil, dan di akhir pembayaran bunga yang mengecil sedangkan pokok besar. 
4) Bunga mengambang, sistem ini besar bunga tergantung atau mengikuti suku bunga pasar. Di mana, jika suku bunganya naik maka besar bunga akan naik pula, dan jika suku bunga pasar turun maka besar bunga juga akan turun.

Sementara metode-metode yang digunakan dalam menentukan nilai waktu uang, antara lain:

a) $M$ etode average rate of return

M etode ini mengukur berapa tingkat keuntungan yang diperoleh suatu investasi atau LABA/INVESTASI.

Jika average rate of return lebih tinggi dari laba yang diharapkan $\rightarrow$ layak.

Kelemahan metode A R R : M engabaikan nilai waktu uang

b) M etode payback period

M engukur seberapa cepat investasi itu kembali.

K riteria penilaian investasi : Semakin cepat semakin baik

Kelemahan M etode payback period : M engabaikan nilai waktu uang.

c) M etode net present value (NPV)

Metode ini menghitung selisih antara nilai sekarang investasi dengan nilai sekarang penerimaan kas bersih dimasa yang akan datang.

$N P V=-$ Investasi $+K$ as thn $1+K$ as thn. $2+\ldots$ Kas thn. $n(1+i) 1(1+i) 2(1+i) n$ dimana i adalah suku bunga bank.

Proyek dinilai layak jika N PV $=$ positif atau Jika NPV $\rightarrow \rightarrow$ layak

d) $M$ etode profitability index (PI)

Metode ini menghitung perbandingan antara nilai sekarang penerimaan kas bersih dimasa yang akan datang dengan nilai sekarang investasi Jika PI lebih dari $1 \rightarrow$ layak.

e) M etode internal rate of return (IRR)

Tingkat discount faktor yang menyamakan nilai sekarang investasi dan nilai sekarang penerimaan kas bersih dimasa yang akan datang.

Jika IRR tabungan atau laba yang disyaratkan $\rightarrow$ layak .

\section{Pandangan E konomi Syariah Tentang Time V alue of M oney.}

Islam memandang uang sebagai flow concept. Uang harus beRp.utar dalam perekonomian dan tidak boleh dibiarkan menganggur dalam waktu yang terlalu lama, apalagi sampai tahunan menjadi idle cash. Islam tidak mengenal metode time value of money karena metode ini menambah nilai kepada uang semata-mata dengan bertambahnya waktu dan bukan usaha. Islam justru mengenal money value of time, yaitu waktu memiliki nilai ekonomi. Sesuai dengan ajaran Islam, manajemen moneter yang efisien dan adil tidak didasarkan pada penerapan metode bunga. ${ }^{2}$

Bagi hasil dalam ekonomi syariah biasa dikenal dengan istilah pembagian laba/PLS (profit and loss sharing) dan revenue sharing (bagi pendapatan). Sedangkan menurut Ali

\footnotetext{
2 Edi W ibowo dan Untung Hendry Widodo, M engapa M emilih Bank Syariah? (B ogor, Ghalia Indonesia, 2005),
} $45-46$ 
Hasan, sistem bagi hasil merupakan salah satu bentuk kerja sama antara pemilik modal dan seseorang, yang dilandasi oleh rasa tolong menolong. Sebab ada orang yang mempunyai modal, tetapi tidak mempunyai keahlian dalam menjalankan roda perusahaan. A da juga orang yang mempunyai modal dan keahlian, tetapi tidak mempunyai waktu. Sebaliknya, ada orang yang mempunyai keahlian dan waktu, tetapi tidak mempunyai modal. ${ }^{3}$

Dalam sumber lain disebutkan bahwa bagi hasil adalah sistem pembagian hasil usaha di mana pemilik bekerja sama dengan pemilik modal untuk melakukan kegiatan usaha. A pabila kegiatan usaha menghasilkan keuntungan maka dibagi berdua dan ketika mengalami kerugian ditanggung bersama pula. Sistem bagi hasil menjamin adanya keadilan dan tidak ada pihak yang terekploitasi. ${ }^{4}$

Ekonomi Islam memberikan solusi supaya uang saat ini di masa mendatang tetap memiliki nilai tinggi meski cenderung mengalami penurunan ketika didiamkan dari waktu ke waktu mengalami inflasi, yakni dengan jalan investasi, menabung dan bisnis (no risk, no return) yang menerapkan sistem bagi hasil (sesuai nisbah) dengan akad mudharabah dan musyarakah untuk produk-produk pembiayaan ekonomi yang berbasis Natural Uncertainty Contracts (NUC), yakni akad bisnis yang tidak memberikan kepastian pendapatan (return), baik dari segi jumlah (amount) maupun waktu (timing). 5 Sementara solusi kedua, dengan margin keuntungan, margin keuntungan hanya digunakan pada produk-produk pembiayaan yang berbasis Natural Certainty Contracts (NCC), yakni akad bisnis yang memberikan kepastian pembayaran, baik dari segi jumlah (amount) maupun waktu (timing), seperti pembiayaan murabahah, ijaroh, salam dan istisna'.6

\section{Kesimpulan}

Berdasarkan kajian yang membahas tentang Nilai W aktu Dari Uang, maka kami dapat menyimpulkan sebagai berikut:

1. Nilai waktu uang merupakan konsep sentral dalam manajemen keuangan atau nilai waktu dari uang di dalam pengambilan keputusan jangka panjang, nilai waktu memegang peranan penting. Konsep nilai waktu uang di perlukan oleh manajer keuangan dalam mengambil keputusan ketika akan melakukan investasi pada suatu aktiva dan pengambilan keputusan ketika akan menentukan sumber dana pinjaman yang akan di pilih.

2. Mengatasi penurunan nilai uang karena tergerus inflasi dan karena tertelan oleh waktu adalah dengan membuat uang tersebut produktif dan atau memberi imbal hasil melebihi laju inflasi. Cara paling efektif adalah menginvestasikan dana tersebut agar menghasilkan imbal hasil di atas laju inflasi sehingga nilai uang yang ada relatif tetap atau bahkan bisa bertambah.

\footnotetext{
${ }^{3}$ M . A li Hasan, B erbagai M acam Transaksi dalam Islam (J akarta: PT Raja Grafindo Persada, 2003), 169

${ }^{4}$ Evi Natalia, Dzulkirom, dan Sri M angesti Rahayu, "Pengaruh Tingkat Bagi Hasil Deposito Bank Syariah dan Suku Bunga Deposito Bank Umum terhadap Jumlah Simpanan Deposito Mudharabah (Studi pada PT Bank Syariah M andiri periode 2009-2012)", dalam J urnal A dministrasi Bisnis (JA B ), V ol. 9, N o. 1, A pril 2014, 3

${ }_{5}^{5}$ A diwarman A. Karim, Bank Islam A nalisis Fiqih dan K euangan (Jakarta: PT RajaGrafindo Persada, 2010), 286

${ }^{6}$ M uhammad Syafi'i A ntonio, B ank Syariah Suatu Pengenalan U mum (J akarta: Cendekia Institute, 1999), 199
} 
3. Selain inflasi kita harus memperhatikan biaya-biaya yang mungkin muncul dalam investasi kita. Seperti yang kita ketahui, sering instrumen yang kita gunakan dalam investasi memerlukan biaya-biaya dalam pengelolaan atau penguasaannya. Terhadap biaya-biaya tersebut maka kita harus sedikit meluangkan waktu dalam menghitungnya. Karena itu, kita harus memahami tentang bunga, konsep nilai waktu dan metode-metode nilai waktu uang.

4. Dalam pandangan ekonomi Islam tidak mengenal metode time value of money karena metode ini menambah nilai kepada uang semata-mata dengan bertambahnya waktu dan bukan usaha yang itu justru mengarah pada transaksi ribawi sebagaimana pendapat Imam Nawawi memberikan definisi terkait penambahan nilai uang yang hanya didasarkan pada nilai waktu adalah kategori riba. Islam justru mengenal money value of time, yaitu waktu memiliki nilai ekonomi. Sesuai dengan ajaran Islam, manajemen moneter yang efisien dan adil tidak didasarkan pada penerapan metode bunga. Namun, di Islam dikenal istilah sistem bagi hasil, baik PLS (profit and loss sharing) ataupun bagi pendapatan (reveneu sharing).

\section{Daftar Rujukan}

A., Deanta, Perencanaan Investasi dan Studi Kelayakan Proyek, Y ogyakarta: Penerbit CV. A ndi Offset, 2006

Antonio, Muhammad Syafi'i Bank Syariah Suatu Pengenalan U mum, Jakarta: Cendekia Institute, 1999

Edi Wibowo dan Untung Hendry Widodo, Mengapa M emilih Bank Syariah?, Bogor: Ghalia Indonesia, 2005

Evi Natalia, Dzulkirom, dan Sri Mangesti Rahayu, Pengaruh Tingkat Bagi Hasil Deposito Bank Syariah dan Suku Bunga Deposito Bank Umum terhadap Jumlah Simpanan Deposito Mudharabah (Studi pada PT Bank Syariah Mandiri periode 2009-2012). Jurnal A dministrasi Bisnis (J A B) Vol. 9 No. 1 A pril 2014

Hasan, M. A li, B erbagai M acam Transaksi dalam Islam, Jakarta: PT Raja Grafindo Persada, 2003

Karim, A diwarman A., Bank Islam A nalisis Fiqih dan K euangan, Jakarta: PT RajaGrafindo Persada, 2010

K asmir dan J akfar, Studi K elayakan Bisnis, J akarta: Prenada M edia, 2003

William R. Lasher, Financial Management: Kelayakan Bisnis, USA: Thomson SouthWestren, 2008

Http///www. Nilai waktu dari uang/M enulis Untuk Belajar, Belajar Untuk M enulis K onsep Nilai Waktu Dari U ang.htm 